\title{
COMBUSTION AND LEACHING BEHAVIOR OF TRACE ELEMENTS IN LIGNITE AND COMBUSTION BY-PRODUCTS FROM THE MUĞLA BASIN, SW TURKEY
}

\author{
Fotopoulou M. ${ }^{1}$, Siavalas G. ${ }^{1}$, İnaner H. ${ }^{2}$, Katsanou K. ${ }^{3}$, Lambrakis N. ${ }^{3}$, \\ and Christanis K. ${ }^{1}$ \\ ${ }^{1}$ Section of Earth Materials, Department of Geology, University of Patras, 26500 Rio-Patras - Greece, \\ mariafot@gmail.com,siavalas@upatras.gr,christan@upatras.gr \\ ${ }^{2}$ Department of Geological Engineering, Dokuz Eylul University, Buca-Izmir-Turkey, \\ hulya.inaner@deu.edu.tr \\ ${ }^{3}$ Section of Applied Geology and Geophysics, Department of Geology, University of Patras, 26500 \\ Rio-Patras - Greece, katsanou@upatras.gr,nlambrakis@upatras.gr
}

\begin{abstract}
The Muğla Basin is one of the most well-documented coal basins of Anatolia, SW Turkey. Previous studies mainly focused on coal geology, as well as on the environmental impacts from trace elements emitted into the atmosphere during coal combustion. However, the environmental impacts from coal utilization also include groundwater contamination from hazardous trace elements leached from exposed lignite stockpiles or ash disposal dumps. In the present study a comparative assessment of the combustion, as well as the leaching behaviour of trace elements from sixteen lignite, fly ash and bottom ash samples under various $\mathrm{pH}$ conditions is attempted. The samples were picked up from three regions in the Mŭ̆la Basin, namely, these of Yeniköy, Kemerköy and Yată̆an.

Proximate and ultimate analyses were performed on all samples. Quantitative mineralogical analysis was carried out using a Rietveld-based full pattern fitting technique. The elements Ag, As, B, Ba, $\mathrm{Be}, \mathrm{Co}, \mathrm{Cr}, \mathrm{Cu}, \mathrm{Fe}, \mathrm{Ga}, \mathrm{Hf}, \mathrm{Li}, \mathrm{Mn}, \mathrm{Mo}, \mathrm{Ni}, \mathrm{Pb}, \mathrm{Sr}, \mathrm{U}, \mathrm{V}$ and $\mathrm{Zn}$ were grouped according to their volatility during combustion and their leachability in the various types of samples. The $\mathrm{pH}$ of the leaching agent little affected the leaching trends of most elements and the mode of occurrence proved to be the major factor controlling primarily combustion and to a lesser extent leaching. The elements were classified into 7 classes with increasing environmental significance with $\mathrm{Mo}$, Sr and V being the most potentially hazardous trace elements in the Muğla region.
\end{abstract}

Key words: bottom ash, fly ash, leachability, lignite, mobility, Muğla, trace elements, Turkey, volatility.

\section{Introduction}

The last decades countries using "conventional" fuels for electricity generation, are attempting to develop a friendlier to the environment, energy policy. The study of the behavior of trace elements, particularly of the hazardous atmospheric pollutants - HAPs (As, $\mathrm{Be}, \mathrm{Cd}, \mathrm{Cl}, \mathrm{Cr}, \mathrm{Co}, \mathrm{F}, \mathrm{Hg}, \mathrm{Mn}, \mathrm{Ni}, \mathrm{Pb}$, $\mathrm{Se}, \mathrm{Sb}$ and $\mathrm{U}$ ), is necessary for the prediction and the prevention of environmental impacts, induced by coal combustion and the disposal of the wastes (Finkelman, 1994; Finkelman and Gross, 1999). The behavior of trace elements in combustion can be assessed studying their geochemical and mineralogical characteristics (Clarke and Sloss, 1992; Meij, 1995). 
There is an extensive literature concerning the determination of HAP behaviour during coal combustion (e.g. Finkelman, 1994; Vassilev et al., 2005). All these studies are based on the fact that an element is enriched in the produced fly and bottom ash due to the escape of the volatile matter during combustion. Elements depleted in comparison to the feed coal are considered volatile and potential HAPs. The volatility of an element depends on its properties but also on its mode of occurence. The mode of occurence of an element can vary not only in different coals but sometimes even in coals from the same deposit. Therefore, it is necessary to study the behavior of the elements for each coal deposit separately.

Apart from atmospheric emissions, coal utilization involves enviromental hazards concerning waste disposal. The impacts are related to the mobilization of toxic metals after the deposition of fly and bottom ash at dump sites. The behavior of an element after the exposure of the waste under the atmospheric conditions can be predicted considering its mode of occurence, but an experimental study using leaching tests provides direct evidence for the most suspectible to mobilization elements. There are two major types of leaching tests concerning their set up: Column tests, which better simulate field conditions, and batch tests, which provide evidence for the maximum potential mobility of an element. Batch tests are more widely applied due to their relatively rapid and reliable results but can easily misinterpreted if only absolute values are to be considered (Siavalas et al., 2007; Baba et al., 2008; Hesbach et al., 2009).

The lignite mining activities in Turkey appear to have serious repercussions in underground waters. Several studies showed that certain trace elements are dissolved from ash dumping sites and pass into the groundwater (e.g. Demirak et al., 2005). Taking into consideration the fact that Turkish lignite displays low calorific value, high ash yield and sulphur content, further research is required to investigate the environmental impacts caused by their exploitation (İnaner and Nakoman, 2005).

The present work aims to investigate the combustion and leaching behaviour of trace elements in lignite, fly ash and bottom ash from the regions of Yatağan and Milas in Muğla Basin. The main focuses are the conditions, under which trace elements are able to escape from the organic and inorganic fraction of lignite, fly- and bottom ash and to be transported in the terrestrial and aquatic environment constituting environmental hazard.

\section{Regional and geological setting}

Muğla Basin is located on the Eastern coast of the Aegean Sea, in southwest Anatolia (Fig. 1). The coal fields are of Miocene age. The basin's margins consist of the formations of the Menderes Massif and the Lycian nappes.

Muğla Basin is separated into two sub-basins: Yatağan and Milas (Fig. 1). The NW-SE oriented Yatağan Sub-basin hosts the lignite deposits of Turgut, Eskihisar, Bagyaka, Tinaz and Bayir, while the sub-basin of Milas includes the lignite deposits of Ekizköy, Sekköy, Cakiralan, Karacahisar, Husamlar and Alatepe (Fig. 1). Open-cast mines operate in the Eskihisar, Bagyaka, Tinaz, Sekköy, Ekizköy, Husamlar, and Cakiralan coal fields. The Alatepe coal field has been exploited by underground mining methods. Bayır, Turgut, and Karacahisar coal fields are to be exploited by underground mining methods in the future. Most of the lignite production supplies three thermal power plants (Fig. 1), these of Yatağan, Yeniköy and Kemerköy with 630, 420 and 630 MW installed capacity, respectively (Querol et al., 1999; İnaner et al., 2008). Electrostatic precipitators and desulphurization units are installed in all 3 power plants and solid wastes are removed and stored by hydro-transportation. Ash-dumping sites have been afforested by authorities of thermal power plants.

The Yatağan thermal power plant produces approximately $5 \mathrm{kt}$ of fly and bottom ash per day. The produced solid wastes are transported to a schist and karstic marble disposal site. The Yeniköy thermal power plant produces daily $4.5 \mathrm{kt}$ of fly and bottom ash. The produced solid wastes are transported 


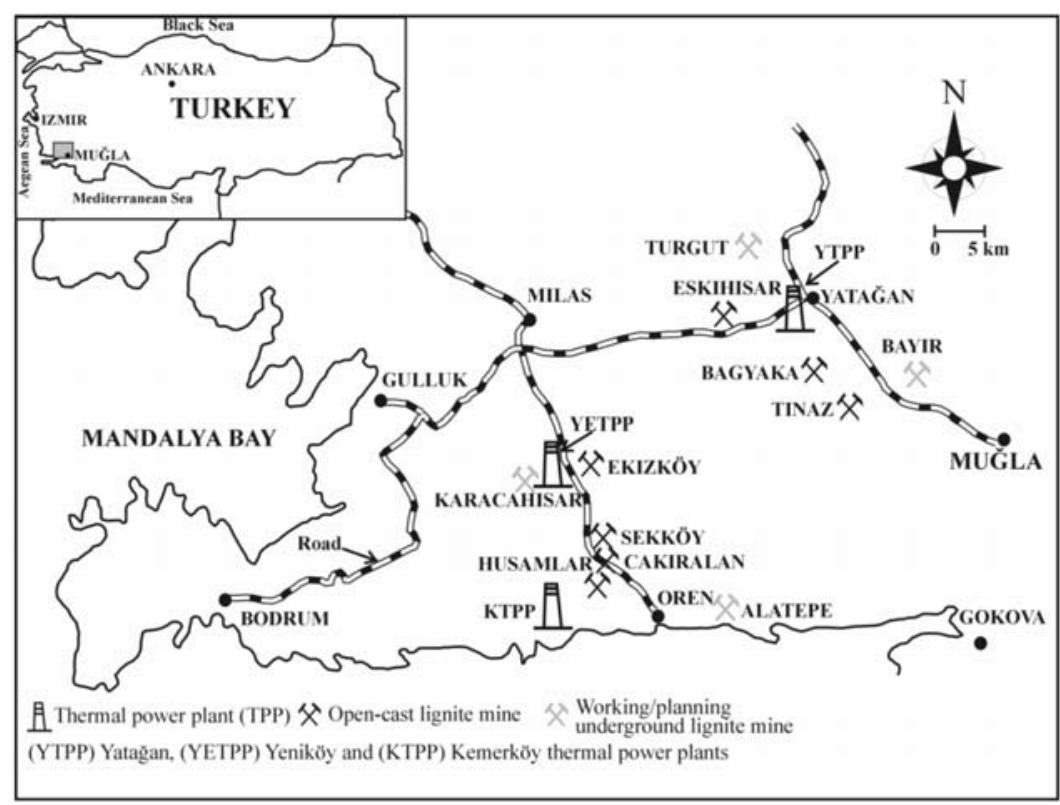

Fig. 1: Thermal power plants and major lignite fields in Muğla Basin (İnaner et al., 2008, modified).

to the disposal site, which is located on alluvial deposits and limestone. The Kemerköy thermal power plant produces c. $6 \mathrm{kt}$ of fly and bottom ash per day. The produced solid wastes are transported to a karstic and fractured dolomitic and cherty limestone disposal site (Baba and Kaya, 2004).

\section{Experimental}

Sixteen samples of lignite, fly ash and bottom ash were collected from mines and thermal power plants in the areas of Milas and Yatağan, in Muğla province. The lignite samples were described macroscopically according to the nomenclature of ICCP (1993). Proximate analysis carried out following ASTM procedures, included the determination of moisture, ash yields, volatile matter and fixed carbon content. In addition, mineralogical analysis was performed in all samples. The contents of $\mathrm{C}, \mathrm{H}$, $\mathrm{N}$ and $\mathrm{S}$ of lignite and lignite combustion by-products were determined using the Carlo Erba EA1108 CHNS analyzer. Quantitative mineralogical analysis was carried out using a Bruker D8 Advance Xray diffractometer, which is equipped with the detector LynxEye ${ }^{\circledR}$, whereas the mineralogical phases were quantified using a routine, which is based on the Rietveld method with the Topas software. All samples were digested in acid solutions using a Milestone microwave oven. The contents of $\mathrm{Ag}, \mathrm{As}$, $\mathrm{B}, \mathrm{Ba}, \mathrm{Be}, \mathrm{Co}, \mathrm{Cr}, \mathrm{Cu}, \mathrm{Fe}, \mathrm{Ga}, \mathrm{Hf}, \mathrm{Hg}, \mathrm{Li}, \mathrm{Mn}, \mathrm{Mo}, \mathrm{Ni}, \mathrm{Pb}, \mathrm{Se}, \mathrm{Sr}, \mathrm{U}, \mathrm{V}$ and $\mathrm{Zn}$ in the digested lignite, fly- and bottom ash samples were determined using an ELAN 6100 Perkin Elmer ${ }^{\circledR}$ instrument (Inductively Coupled Plasma-Mass Spectrometry, ICP-MS). Batch leaching experiments took place under pH 5 and 8.5 to estimate the mobility of trace elements from lignite and its by-products.

\section{Results}

\subsection{Proximate analysis}

The lignite belongs to the matrix lithotype. Moisture ranges from 14.0 to $36.5 \mathrm{wt} . \%$, ash yield from 8.4 to $50.3 \mathrm{wt} . \%$, where the highest ash yields concern the feed coal samples of the area. The calorific 
Table 1. Quantitative mineralogical analysis of bulk coal samples, low-temperature $\left(400^{\circ} \mathrm{C}\right)$ ash, fly ash and bottom ash samples. $\mathrm{GoF}\left(\mathrm{x}^{2}\right)$ : Goodness of Fit factor.

\begin{tabular}{|c|c|c|c|c|c|c|c|c|c|c|c|c|c|c|c|}
\hline & 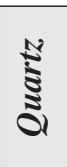 & $\frac{2}{5}$ & $\frac{\tilde{\Xi}}{\tilde{U}}$ & 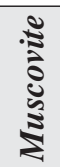 & 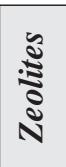 & $\frac{0}{0}$ & 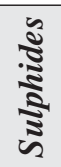 & 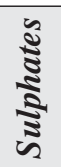 & 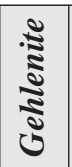 & 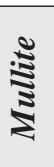 & : & \begin{tabular}{l}
2 \\
\multirow{2}{*}{} \\
$\vdots$ \\
0 \\
0 \\
1 \\
1
\end{tabular} & 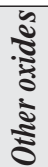 & 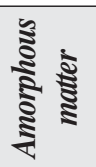 & $\underbrace{\frac{3}{3}}_{0}$ \\
\hline TR-L1 & 19.2 & & & & & & 80.8 & & & & & & & & 1.5 \\
\hline TR-L2 & 11.7 & 19.4 & 11.6 & 39.3 & & & 9.4 & 8.5 & & & & & & & 1.1 \\
\hline TR-L3 & 39.0 & 14.2 & 28.7 & 18.1 & & & 7.1 & & & & & & & & 1.6 \\
\hline TR-L3a & 49.4 & & 27.6 & 23.0 & & & 6.2 & 5.8 & & & & & & & 1.6 \\
\hline TR-L4 & 13.5 & 14.7 & 35.4 & 33.8 & & & 2.5 & & & & & & & & 1.6 \\
\hline TR-L5 & 8.9 & 4.0 & 58.8 & 2.5 & & 20.5 & 1.6 & 6.1 & & & & & & & 1.2 \\
\hline TR-L6 & 12.1 & 5.7 & 47.3 & 11.7 & & 18.7 & 1.6 & 14.4 & & & & & & & 1.2 \\
\hline TR-L1 LTA & 7.7 & 10.7 & 4.8 & & & & & 71.6 & & & & 5.1 & & & 1.5 \\
\hline TR-L2 LTA & 6.2 & 4.0 & 66.0 & & & & & 19.2 & & & & 5.1 & & & 1.2 \\
\hline TR-L3 LTA & 9.8 & 4.7 & 52.6 & & & & & 33.0 & & & & & & & 1.5 \\
\hline TR-L3a LTA & 23.0 & & 4.3 & & & & & 72.8 & & & & & & & 1.6 \\
\hline TR-L4 LTA & 5.4 & 3.4 & 74.7 & & & & & 11.8 & & & & 2.0 & & & 1.3 \\
\hline TR-L5 LTA & 10.3 & 4.5 & 45.8 & & & 22.5 & & 15.5 & & & & 1.4 & & & 1.3 \\
\hline TR-L6 LTA & 11.8 & 6.6 & 40.2 & & & 21.6 & & 17.7 & & & & 2.1 & & & 1.4 \\
\hline TR-AF1 & 3.2 & 3.2 & 0.7 & & & & & 5.8 & 7.5 & 2.4 & 4.0 & 2.3 & 4.1 & 66.8 & 2.3 \\
\hline TR-AF2 & 10.1 & 18.2 & & & & & & 3.6 & 4.8 & 5.6 & 0.7 & 5.2 & & 51.8 & 1.2 \\
\hline TR-AF3 & 4.1 & 1.5 & & & & & & 14.7 & 12.2 & 0.8 & 4.6 & 3.9 & & 58.2 & 1.5 \\
\hline TR-AF4 & 7.5 & 9.5 & & & & & & 1.3 & 2.2 & 3.3 & 0.8 & 2.3 & & 73.1 & 1.2 \\
\hline TR-AF5 & 6.4 & 6.6 & & & & & & 6.0 & 7.0 & 2.5 & 2.6 & 4.0 & & 64.9 & 1.3 \\
\hline TR-AB1 & 2.1 & 4.7 & & & 4.7 & 3.5 & & & 23.6 & & & 1.3 & & 60.1 & 1.4 \\
\hline TR-AB2 & 3.7 & 9.9 & & & 12.7 & 7.6 & & 3.6 & 20.2 & & & 2.8 & & 39.4 & 1.8 \\
\hline TR-AB3 & 5.1 & 20.5 & & & 9.0 & 2.3 & & & 8.9 & & 1.2 & 2.5 & 1.2 & 49.4 & 1.4 \\
\hline TR-AB4 & 10.9 & 13.5 & & & 4.6 & & & & 2.2 & 1.8 & 0.6 & 1.5 & & 65.0 & 1.6 \\
\hline
\end{tabular}

value ranges from 10.6-20.9 MJ/kg (on moist, ash-free basis). The content of volatile matter ranges from 44.1 to $67.1 \mathrm{wt} . \%$ and of fixed carbon from 5.6 to $29.0 \mathrm{wt} . \%$. According to these results the Muğla lignite is classified as low to medium-grade, humic, ortho- to meta-lignite (ECE-UN, 1998).

The fly ash is composed of fine-grained particles and the volatile matter content ranges from 0.6 to $1.1 \mathrm{wt} . \%$. The volatile matter content in bottom ash ranges from 0.7 to $8.5 \mathrm{wt} . \%$.

\subsection{Mineralogical analysis}

The accuracy of the quantitative mineralogical analysis was checked using the Goodness of Fit (GoF) rule, where the more the GoF value approaches 1 the better fit was achieved (Bish and Post, 1992). This value ranges between 1.1 and 2.3 with an average of 1.4 for the studied samples indicating that a good fit was achieved (Table 1).

The inorganic constituents of coals may be introduced into the peat either as clastic material or may derive from authigenic precipitation. However, in the study of bulk coal samples due to high noise/signal ratio caused by the organic matter, it is hard to determine some mineral phases. For this reason mineralogical analyses were also performed on ash derived after low temperature $\left(400^{\circ} \mathrm{C}\right)$ ashing (LTA) in order to remove the organic matter without altering much the mineralogical composition (Table 1). 
According to the combined results from both bulk samples and LTAs the most common mineralogical components in the Muğla lignite are quartz, feldspars, carbonates, clay minerals mainly illite and kaolinite, all being common in coals worldwide (Diessel, 1992).

The major minerals in fly ash samples are quartz, anhydrite and aluminosilicate minerals such as feldspars, mullite and gehlenite. There are also ferrous and calcium oxides such as magnetite, hematite, maghemite, portlandite and lime. The mineralogical composition of bottom ash samples is somewhat different to that of the fly ash. Ghelenite is the dominant phase being more stable at low temperatures. Calcite content is also higher probably due to the contribution of lignite particles in the bottom ash. Quartz and aluminosilicates are present at lower contents than in the fly ash. Moreover, minerals from the zeolite group were determined at relatively high contents (16 wt.\%, on average). The zeolites form from the reaction of glass with water in the combustion chamber (Karayiğit et al., 2000). Bassanite and corundum are occasional minerals.

Furthermore, the content of amorphous matter in fly and bottom ash samples was determined in $\mathrm{ZnO}$ spiked samples. Amorphous matter content in the fly ash ranges from 51.8 to $71.3 \mathrm{wt}$. $\%$ being higher than the respective in the bottom ash, which ranges from 39.4 to $65.0 \mathrm{wt} \% \%$ (Table 1).

\subsection{Chemical composition}

In the lignite samples $\mathrm{C}$ ranges from 42.2 to $52.5 \mathrm{wt} . \%, \mathrm{~N}$ from 1.2 to $1.4 \mathrm{wt} . \%, \mathrm{H}$ from 5.7 to 7.8 wt.\% and total S from 2.7 to $7.9 \mathrm{wt} . \%$, on a dry basis. The content of $\mathrm{C}$ in fly ash samples ranges from 0.2 to $0.3 \mathrm{wt} . \%$, of $\mathrm{H}$ is about $0.1 \mathrm{wt} . \%$, of $\mathrm{N}$ is below $0.1 \mathrm{wt} . \%$ and of total $\mathrm{S}$ from 0.4 to 1.4 wt. \%. Finally, the content of $\mathrm{C}$ ranges from 0.5 to $1.9 \mathrm{wt} . \%$, of $\mathrm{H}$ from 0.0 to $0.7 \mathrm{wt} \%$, of $\mathrm{N}$ below 0.1 wt.- $\%$ and of S from 0.0 to 1.3 wt.\% in the bottom ash.

The Fe concentration in the lignite samples ranges from 0.2 to $1.7 \mathrm{wt} . \%$ being probably related to pyrite; it is also possible to participate in clay minerals. The average concentrations of $\mathrm{Ag}, \mathrm{As}, \mathrm{Cd}$, $\mathrm{Cr}, \mathrm{Ga}, \mathrm{Li}, \mathrm{Mo}, \mathrm{Ni}, \mathrm{Pb}, \mathrm{Sr}, \mathrm{U}, \mathrm{V}$ and $\mathrm{Zn}$ in the lignite samples are higher than the average world coal concentration (Table 2). The determination of $\mathrm{Hg}$ and $\mathrm{Se}$ is not accurate, due to their high volatility and the results for these elements are treated with skepticism.

Strontium exceeds $100 \mathrm{mg} / \mathrm{kg}$ in the lignite, while the concentrations of many elements as $\mathrm{Ba}(21$ $227 \mathrm{mg} / \mathrm{kg}), \mathrm{Mn}(23-173 \mathrm{mg} / \mathrm{kg}), \mathrm{Ni}(9-153 \mathrm{mg} / \mathrm{kg})$ and V (59-163 mg/kg) display a wide range among the bulk samples. The contents of $\mathrm{As}, \mathrm{B}, \mathrm{Co}, \mathrm{Cr}, \mathrm{Cu}, \mathrm{Ga}, \mathrm{Li}, \mathrm{Mo}, \mathrm{Pb}, \mathrm{U}, \mathrm{Zn}$ have contents vary from $1 \mathrm{mg} / \mathrm{kg}$ to $100 \mathrm{mg} / \mathrm{kg}$, whereas these of $\mathrm{Ag}$, Be, Cd, $\mathrm{Hf}, \mathrm{Hg}$ are $<1 \mathrm{mg} / \mathrm{kg}$. The elements $\mathrm{Ag}, \mathrm{As}, \mathrm{B}, \mathrm{Ba}, \mathrm{Be}, \mathrm{Cd}, \mathrm{Co}, \mathrm{Cr}, \mathrm{Cu}, \mathrm{Fe}, \mathrm{Ga}, \mathrm{Hf}, \mathrm{Li}, \mathrm{Mn}, \mathrm{Ni}, \mathrm{Mo}, \mathrm{Zn}$ display strong correlation with the ash yields suggesting an inorganic affinity, whereas the weak correlation of B, Mo, Sr, V, U and ash yield indicates an intermediate affinity (organic-inorganic) for these elements.

Element concentrations in fly ash samples were compared to those corresponding to the average crust composition (Table 2). It appears that $\mathrm{As}, \mathrm{B}, \mathrm{Li}, \mathrm{Mo}, \mathrm{Ni}, \mathrm{Pb}, \mathrm{U}, \mathrm{V}$ and $\mathrm{Zn}$ are enriched. The concentrations of $\mathrm{Ag}, \mathrm{Cd}, \mathrm{Cu}, \mathrm{Ga}$ present higher values in comparison to these of the crust, but not as high as the elements that were mentioned before. Barium, Co, Cr, Hf, Mn, and Sr display lower average concetrations in the fly ash samples than in the crust (Table 2).

The Fe content ranges from 0.9 to $2.9 \mathrm{wt} . \%$ in bottom ash with an average of $1.6 \mathrm{wt} . \%$. Mn, Sr, V and $\mathrm{Zn}$ have contents higher than $100 \mathrm{mg} / \mathrm{kg}$, while the contents of $\mathrm{Ag}, \mathrm{Be}, \mathrm{Cd}, \mathrm{Co}, \mathrm{Cr}, \mathrm{Cu}, \mathrm{Ga}, \mathrm{Hf}$, $\mathrm{Hg}, \mathrm{Li}, \mathrm{Mo}, \mathrm{Ni}, \mathrm{Pb}, \mathrm{Se}$ and $\mathrm{U}$ range lower than $100 \mathrm{mg} / \mathrm{kg}$. The elements As, B, U, V and Zn display very high average values in the bottom ash. Beryllium, $\mathrm{Co}, \mathrm{Cu}, \mathrm{Hf}, \mathrm{Mn}$, and $\mathrm{Sr}$ display lower 
Table 2. Average concentrations (in $\mathrm{mg} / \mathrm{kg}$, if not otherwise stated) of trace elements in Muğla lignite, fly and bottom ash in comparison to worldwide coal (Clarke and Sloss, 1992) and upper crust average values (Seredin and Finkelman, 2008).

\begin{tabular}{|c|c|c|c|c|c|c|c|}
\hline Element & Lignite & $\begin{array}{c}\text { Fly } \\
\text { ash }\end{array}$ & $\begin{array}{c}\text { Enrichment } \\
\text { Factor }\end{array}$ & $\begin{array}{c}\text { Bottom } \\
\text { ash }\end{array}$ & $\begin{array}{c}\text { Enrichment } \\
\text { Factor }\end{array}$ & Crust & $\begin{array}{c}\text { Worldwide } \\
\text { coals }\end{array}$ \\
\hline $\mathrm{Fe}(\%)$ & 0.7 & 2 & & 1.6 & & & \\
\hline $\mathrm{Ag}$ & 0.1 & 0.3 & 0.63 & 0.3 & 0.61 & 0.1 & 0.1 \\
\hline $\mathrm{As}$ & 21 & 131 & 1.56 & 24 & 0.29 & 1 & 7.6 \\
\hline $\mathrm{B}$ & 38 & 167 & 1.07 & 100 & 0.64 & 10 & 56 \\
\hline $\mathrm{Ba}$ & 86 & 296 & 0.84 & 280 & 0.80 & 425 & 150 \\
\hline $\mathrm{Be}$ & 0.5 & 3 & 1.29 & 2 & 1.10 & 3 & 1.2 \\
\hline $\mathrm{Cd}$ & 0.4 & 2 & 1.04 & 0.6 & 0.37 & 0.2 & 0.2 \\
\hline $\mathrm{Co}$ & 4 & 17 & 1.07 & 15 & 0.93 & 25 & 4.2 \\
\hline $\mathrm{Cr}$ & 35 & 93 & 0.66 & 76 & 0.54 & 100 & 15 \\
\hline $\mathrm{Cu}$ & 12 & 65 & 1.32 & 52 & 1.04 & 55 & 15 \\
\hline $\mathrm{Ga}$ & 8 & 32 & 0.93 & 24 & 0.70 & 15 & 5.5 \\
\hline $\mathrm{Hf}$ & 0.4 & 2 & 1.07 & 2 & 0.95 & 20 & 1.2 \\
\hline $\mathrm{Hg}$ & 0.4 & - & - & - & - & 0.08 & 0.1 \\
\hline $\mathrm{Li}$ & 13 & 71 & 1.30 & 58 & 1.06 & 20 & 10 \\
\hline $\mathrm{Mn}$ & 77 & 314 & 0.98 & 295 & 0.93 & 950 & 153 \\
\hline $\mathrm{Mo}$ & 10 & 29 & 0.69 & 17 & 0.42 & 2 & 2.2 \\
\hline $\mathrm{Ni}$ & 40 & 100 & 0.62 & 93 & 0.57 & 75 & 9.0 \\
\hline $\mathrm{Pb}$ & 10 & 41 & 1.03 & 17 & 0.44 & 13 & 6.6 \\
\hline $\mathrm{Se}$ & - & - & - & - & - & 0.05 & 1.0 \\
\hline $\mathrm{Sr}$ & 370 & 294 & 0.20 & 372 & 0.25 & 375 & 120 \\
\hline $\mathrm{U}$ & 30 & 56 & 0.47 & 64 & 0.53 & 2 & 2.9 \\
\hline $\mathrm{V}$ & 124 & 255 & 0.52 & 242 & 0.49 & 135 & 22 \\
\hline $\mathrm{Zn}$ & 61 & 220 & 0.89 & 131 & 0.53 & 70 & 18 \\
\hline
\end{tabular}

contents in the bottom ash compared to the crust (Table 2). The ash samples are enriched in most of the trace elements due to the loss of volatile elements during combustion.

\subsection{Behavior of elements during combustion}

In order to estimate the mobility of the studied elements, the relative enrichment factor (EF) was calculated using a formula introduced by Meij (1995) (Table 2). It constitutes a measure of the concentration of an element in the bulk coal sample and its produced ash (Meij \& te Winkel, 2009; Vejahati et al., 2009). Elements with $\mathrm{EF}>0.7$ are considered enriched, these with $\mathrm{EF}<0.5$ non-enriched, and these with $0.5<\mathrm{EF}<0.7$ slightly enriched. According to the calculated $\mathrm{EFs} \mathrm{B}, \mathrm{Mo}, \mathrm{Sr}, \mathrm{U}$ and $\mathrm{V}$ are the most volatile elements, whereas $\mathrm{Ag}, \mathrm{As}, \mathrm{Be}, \mathrm{Cd}, \mathrm{Cr}, \mathrm{Ga}, \mathrm{Ni}, \mathrm{Pb}$ and $\mathrm{Zn}$ display medium volatility. Barium, $\mathrm{Co}, \mathrm{Cu}, \mathrm{Hf}, \mathrm{Li}$ and $\mathrm{Mn}$ are non-volatile elements.

\subsection{Leaching}

The concentration of an element in the leachate solutions is a function of both total element concentration in the sample and leaching behavior. For this reason the calculation of indices, which in- 

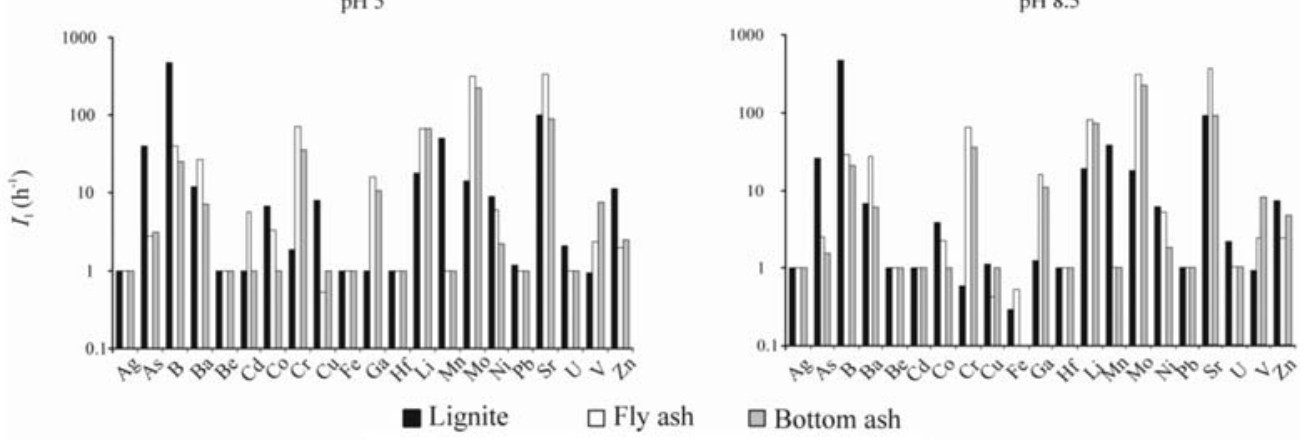

Fig. 2: Element Leaching Intensities $\left(I_{1}\right)$ in the Muğla lignite, fly ash and bottom ash.

volve total element concentration is a common practice used to describe the leaching behavior of an element.

In the present study the Leaching Intensity $\left(I_{1}\right)$ was calculated in order to describe the leaching rate with respect to the leaching time (Wang et al., 1999):

$$
I_{l}=\frac{a_{\mathrm{x}} \times V \times 10^{3}}{A_{x} \times M \times t}
$$

where $\alpha_{\mathrm{x}}$ the concentration of an element $\mathrm{x}$ in the leachate $(\mathrm{mg} / \mathrm{ml}), V$ the total volume of the leachate solution $(\mathrm{ml}), A_{\mathrm{x}}$ the concentration of the element $\mathrm{x}$ in the original sample $(\mathrm{mg} / \mathrm{g}), M$ the sample weight (g) used for the leaching experiment and $t$ the leaching time (h). The stronger the $I_{1}$, the highest the leaching rate of an element. The leachability of an element is distinguished in four classes according to its $I_{1}$. Strong leachability display elements with $I_{1} \geq 5$, medium with $1 \leq I_{1}<5$, weak with $0.5 \leq I_{1}<1$ and very weak with $I_{1}<0.5$ (Wang et al., 1999).

Arsenic, B, Ba, Cu, Li, Mn, Ni, Zn and Sr have strong leachability at all pH values in lignite samples except for $\mathrm{Cu}$ and $\mathrm{Zn}$ which reduce their leachability under alkaline conditions from strong to medium. Chromium displays medium leachability under acidic and alkaline condtitions (Fig. 2). Boron, $\mathrm{Ba}, \mathrm{Cr}, \mathrm{Ga}, \mathrm{Li}, \mathrm{Mo}, \mathrm{Ni}, \mathrm{Sr}$ have strong leachability at all $\mathrm{pH}$ values in the fly ash samples, whereas As, Co, V and Zn have medium leachability with Co leachability turned to weak under alkaline conditions. Finally, B, Ba, Cr, Ga, Li, Mo, Sr, V display strong leachability at all pH values in bottom ash samples and $\mathrm{As}, \mathrm{Ni}, \mathrm{Zn}$ have medium leachability, except for $\mathrm{Zn}$ which increases its leachability to strong under alkaline conditions.

\section{Discussion}

Volatility and leachability are considered the major properties, which define the environmental significance of an element. The former predicts the combustion behaviour and the latter the potential release of an element from the dump sites and the hazard for groundwater contamination. Both properties were divided into three classes including high, moderate and low volatile/leachable elements (Fig. 3).

High volatile elements are $\mathrm{Sr}, \mathrm{Mo}, \mathrm{U}$ and $\mathrm{V}$, whereas the volatility of most of the elements seems to be moderate. Manganese, $\mathrm{Li}, \mathrm{Ba}, \mathrm{Cu}, \mathrm{Co}$ and $\mathrm{Hf}$ are the least volatile elements. The correlation of element concentrations and mineralogical composition indicates that the most volatile elements in 


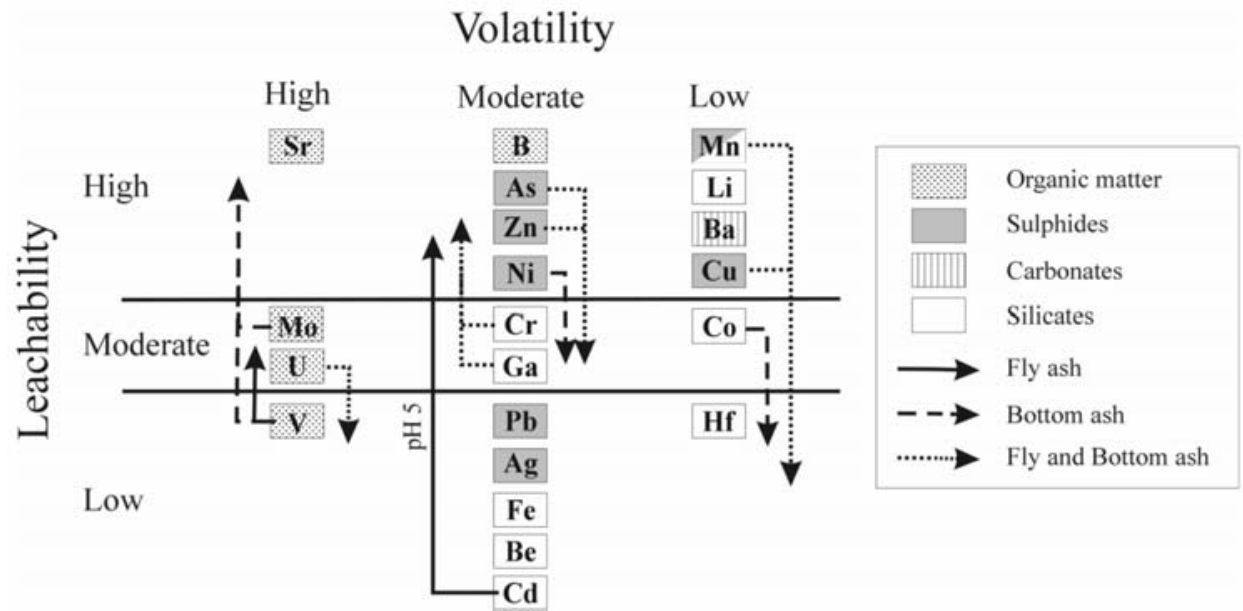

Fig. 3: The mode of occurrence and the classification of the elements according to their combustion and leaching behaviour in the Muğla lignite. Arrows indicate the shift of leaching behaviour in the ash samples.

the Muğla lignite display a mixed affinity between mineral and organic matter probably forming organometallic compounds or being adsorbed on the organic matter (e.g. Wang et al., 1999). Sulphide-bound elements display a moderate volatility except from $\mathrm{Cu}$ (Fig. 3), whereas elements affiliated to the carbonates and the silicates appear to be low or non-volatile.

All elements display almost the same leaching behaviour for the same sample type under both initial $\mathrm{pH}$ values of the leaching agent except from $\mathrm{Cd}$, which proves to be highly mobile in the fly ash under $\mathrm{pH}$ 5. The elements B and $\mathrm{Sr}$ seem to be the most mobile elements in the lignite indicating that the organic affinity is responsible for the high leaching rate of an element, as well. However, other organically-bound elements such as $\mathrm{U}$ and $\mathrm{V}$ display moderate and low mobility in the lignite suggesting that the mode of occurrence of an element is not the exclusive factor influencing an element's mobility. This is also supported by the fact that other elements such as $\mathrm{As}, \mathrm{Ba}, \mathrm{Cu}, \mathrm{Li}, \mathrm{Mn}$, $\mathrm{Ni}$ and $\mathrm{Zn}$ with different modes of occurrence seem to be high mobile in the lignite. Most of them display an affinity to the sulphide phase but others like $\mathrm{Ba}$ and $\mathrm{Li}$ are related to other phases (Fig. 3). The elements affiliated with the silicate phase are low or non-mobile.

Generally, most of the elements are redistributed during combustion due to volatilization and recondensation reactions participating either on the surface or in the matrix of the ash particles. Elements distributed on the ash surface tend to be more mobile but most of the trace elements are less likely to be released due to their adsorption on less soluble aluminosilicates and oxide phases in fly ash and bottom ash samples (Yuan, 2009). The elements $\mathrm{Sr}, \mathrm{B}, \mathrm{Li}, \mathrm{Ba}, \mathrm{Pb}, \mathrm{Ag}, \mathrm{Fe}, \mathrm{Be}$ and $\mathrm{Hf}$ do not display a shift in their leaching behaviour during the transition from the lignite to the ash state. The surface distribution seems to be the most probable reason for the high mobile and organically-bound elements ( $\mathrm{Sr}, \mathrm{Mo}, \mathrm{B})$. These three elements are usually among the most mobile in both coal and the produced ashes (e.g. Wang et al., 1999; Georgakopoulos et al., 2002; Praharaj et al., 2002; Ward et al., 2009). Especially Mo is mobile under all pH values between 2 and 8.5 (Siegel, 2002). The majority of the elements, affiliated to the sulphide phase in the lignite, displays a profound decrease in their leachability in both fly and bottom ash. The breakdown of sulphides and the formation of stable secondary oxides or other more complex compounds is considered responsible for this change. Particularly for As the decrease of its mobility in the ash state has also been reported from other 
coals worldwide and is due to the formation of the arsenate oxyanion, which reacts with calcium to form calcium arsenate (Jones, 1995). However, although Ca acts as an immobilizing agent for other elements such as B, its action in the Muğla ashes seems to be limited, probably due to its low concentration as suggested by the low calcite and lime contents in the lignite and ash, respectively. Elements with increased mobility in the ash samples are $\mathrm{Cr}$, Ga and $\mathrm{V}$, whereas $\mathrm{Cd}$ increased its mobility in the fly ash under acidic conditions.

Aside volatility and leachability the total concentration of an element has to be considered in order to discuss the environmental significance of a certain element. When compared to the average of coals worldwide the Muğla lignite is enriched in As, Cr, Mo, Ni, Sr, U, V and Zn. In the fly and bottom ash samples all elements are enriched compared to the average upper crust concentrations. Additionally, it has been shown that certain elements including $\mathrm{As}, \mathrm{Mn}, \mathrm{Mo}$ and $\mathrm{Pb}$ are susceptible for soil contamination in Yatağan region, although high Mn concentrations are attributed to the use of fertilizers in the area (Baba, 2002).

\section{Conclusions}

Muğla lignite is a low rank coal of medium to poor quality, thus the estimation of environmental impacts from its utilization is necessary. Trace element and mineralogical analyses reveal that the mode of occurrence of the elements is the major factor controlling their combustion behaviour with the most volatile being these, exhibiting a mixed organic/inorganic affinity ( $\mathrm{Sr}, \mathrm{Mo}, \mathrm{U}, \mathrm{V}$ and B). Sulphide related elements are next in the volatility string, whereas elements bound to the silicate minerals seem to be the less volatile.

The mode of occurrence also controls the leaching behaviour but other factors such as the physicochemical properties of individual elements have to be considered. The majority of elements display identical leaching behaviour under both acidic and alkaline environments. Additionally, the change of state from lignite to ash affects mostly the behaviour of elements affiliated to the sulphide phase decreasing their leaching rates.

Based on both combustion and leaching behaviour all trace elements in the Muğla lignite can be distinguished in the following classes with increasing environmental concern:

- Ia: non-volatile/non-mobile elements - $\mathrm{Co}, \mathrm{Cu}, \mathrm{Hf}$,

- Ib: non-volatile/lignite mobile elements - Ba, Mn, Li,

- IIa: moderately volatile/low mobile - Ag, $\mathrm{Be}, \mathrm{Fe}, \mathrm{Pb}$,

- IIb moderately volatile/lignite mobile - As, $\mathrm{Ni}, \mathrm{Zn}$,

- III moderately volatile/high mobile - B, Cd, Cr, Ga,

- IVa: high volatile/low mobile - U and

- IVb: high volatile/high mobile - Mo, Sr, and V.

\section{References}

Baba, A., 2002. Geochemical assessment of environmental effects of ash from Yatağan (Muğla-Turkey) thermal power plant. Water, Air, and Soil Pollution, 144, 3-18.

Baba, A. \& Kaya A., 2004. Leaching characteristics of solid wastes from thermal power plants of western Turkey and comparison of toxicity methodologies. Journal of Environmental Management, 73, 199-207. 
Baba, A., Gurdal, G., Sengunalp, F. \& Ozay, O., 2008. Effects of leachant temperature and pH on lechability of metals from fly ash. A case of study: Can thermal power plant, province of Canakkale, Turkey. Enviromental Monitoring and Assesment, 139, 287-298.

Bish, D.L. \& Post, J.E., 1993. Quantitative mineralogical analysis using the Rietveld full-pattern fitting method. American Mineralogist, 78, 932-940.

Clarke, L.B. \& Sloss, L.L., 1992. Trace elements-emissions from coal combustion and gasification. London, IEA Coal Research, 111.

Demirak, A., Balci, A., Dalman Ö. \& Tüfekci, M., 2005. Chemical investigation of water resources around the Yatağan thermal power plant of Turkey. Water, Air and Soil pollution 162, 171-181.

Diessel, C.F.K., 1992. Diessel, C.F.K., 1992. Coal-Bearing Depositional Systems. Springer Verlag, Berlin . $721 \mathrm{pp}$

Economic Commission for Europe-United Nations (ECE-UN), 1998. International Classification of InSeam Coals. United Nations, Geneva. 42 pp.

Finkelman, R.B., 1994. Modes of occurrence of potentially hazardous elements in coal: levels of confidence. Fuel Processing Technology, 39, 21-34.

Finkelman, R.B. \& Gross, P.M.K., 1999. The types of data needed for accessing the environmental and human impacts of coal. International Journal of Coal Geology, 40, 90-101.

Georgakopoulos, A., Filippidis, A., Kassoli-Fournaraki, A., Fernández-Turiel, J.L., Llores, J.F. \& Mousty, F., 2002. Leachability of major and trace elements of fly ash from Ptolemais Power Station, Northern Greece. Energy Sources, 24, 103-111.

Hesbach, P., Kim, A.G., Abel, A. \& Lamey, S., 2009. Serial batch leaching procedure for characterization of coal fly ash. Enviromental Monitoring Assesment, in press (available online).

İnaner, H. \& Nakoman, E., 2005. Properties of lignite deposits in Western Turkey. Abstract Book 57th Annual Meeting of the ICCP, Patras, 11.

İnaner, H., Nakoman, E. \& Karayiğit, A.I., 2008. Coal resource estimation in the Bayir Field, YatağanMuğla, SW Turkey. Energy Sources, Part A, 30, 1000-1015.

International Committee for Coal Petrology (ICCP), 1993. International Handbook of Coal Petrography, Supplement, Commission I, 19.

Jones, D.R., 1995. The leaching of major and trace elements from coal ash. In: Environmental Aspects of Trace Elements in Coal, Swaine, D.J. and Goodarzi, F. (eds). The Netherlands, Kluwer Academic Publishers, 221-262.

Karayiğit, A.I., Gayer, P. A., Querol, X. \& Onacak, T., 2000. Contents of major and trace elements in feed coals from Turkish coal-fired power plants. International Journal of Coal Geology, 44, 169-184.

Meij, R., 1995. The distribution of trace elements during the combustion of coal. In: Environmental Aspects of Trace Elements in Coal, Swaine, D.J. and Goodarzi, F. (eds). The Netherlands, Kluwer Academic Publishers, 111-127.

Meij, R. \& te Winkel, B.H., 2009. Trace elements in world steam coal and their behaviour in Dutch coalfired power stations: A review. International Journal of Coal Geology 77, 289-293.

Praharaj, T., Powell, M.A., Hart, B.R. \& Tripathy, S., 2002. Leachability of elements from sub-bituminous coal fly ash from India. Environment International, 27, 609-615.

Querol, X., Alastuey, A., Plana, F., Lopez-Soler, A., Tuncali, E., Toprak, S., Ocakoglu, F., \& Koker, A., 1999. Coal geology and coal quality of the Miocene Mugla basin, southwestern Anatolia, Turkey. International Journal of Coal Geology, 41, 311-332.

Seredin, V. and Finkelman, R., 2008. Metalliferous coals: A review of the main genetic and geochemical types. International Journal of Coal Geology, 76, 253-289. 
Siavalas, G., Zilakou, S., Kalaitzidis, S., Chatziapostolou, A., Bouzinos, A. \& Christanis, K., 2007. Trace element lechability from lignite and combustion by-products under certain $\mathrm{pH}$ conditions. Proceedings of the 10th International Conference on Enviromental Science and Technology, Kos Island, 5-7 September.

Siegel, F.R., 2002. Environmental Geochemistry of Potentially Toxic Metals. Springer-Verlag, BerlinHeidelberg, Germany, 218 pp.

Vassilev, S.V., Vassileva, C.G., Karayigit, A.I., Bulut, Y., Alastuey, A. \& Querol, X., 2005. Phase-mineral and chemical composition of composite samples from feed coals, bottom ashes and fly ashes at the Soma power station, Turkey. International Journal of Coal Geology, 61, 35-63.

Vejahati, F., Xu, Z. \& Gupta, R., 2009. Trace elements in coal: Associations with coal and minerals and their behavior during coal utilization - A review. Fuel, in press (available online).

Wang Y., Ren D. \& Zhao F., 1999. Comparative leaching for trace elements in raw coal, laboratory ash, fly ash and bottom ash. International Journal of Coal Geology, 40, 103-108.

Ward, C. R., French, D., Jankowski, J., Dubikova, M., Li, Z. \& Riley K. W., 2009. Element mobility from fresh and long-stored acidic fly ashes associated with an Australian power station. International Journal of Coal Geology, 80, 224-236.

Yuan, C.G., 2009. Leaching characteristics of metals in fly ash from coal-fired power plant by sequential extraction procedure. Microchimica Acta, 165, 91-96. 